\title{
Payment for environmental service of conservation in Cokro Tulung spring, Klaten regency, Indonesia
}

\author{
Faisal $^{1, *}$, Evi Gravitiani $^{2}$, Suryanto $^{2}$, and Mugi Raharjo ${ }^{2}$ \\ ${ }^{1}$ Magister of Economics Development Studies, Faculty of Economy and Business, Sebelas Maret University, Solo, Indonesia \\ ${ }^{2}$ Sustainable Development and Green Business Research Group, Faculty of Economy and Business, Sebelas Maret University, Solo, \\ Indonesia
}

\begin{abstract}
This study aims to: (1) determine the conservation of water resources willingness to pay (WTP) of the community, (2) determine the determinants that significantly affect the value of PAPs for additional benefits due to increase management of water resources conservation, and (3) determine whether reforestation environment is a type of conservation that community desires. Respondents from this study are Surakarta citizens, precisely in the southern region of Surakarta, Laweyan District, Central Java. They are customers of Surakarta Municipal Water Supply Company, especially the water distribution of the Cokro Tulung spring. This study uses linear analysis and Contingent Valuation Method (CVM). The interviews result with 106 respondents revealed that: (1) the average value of WTP in R2 is Rp 1,872,-, the average value of WTP in R3 is Rp 3,238,-, the average value of WTP in R4 is Rp 2,769,-, and the average value of WTP in trade group 1 is $R p 3,846,-$, (2) education variables and perception variables on the importance of conservation have a significant effect on WTP of conservation of water resources, and (3) survey results show that there are $73.6 \%$ of respondents intend to do greening around Cokro Tulung spring.
\end{abstract}

\section{Introduction}

Water is a part of basic needs and one of natural resources that has an important purpose for all living beings, included humans. A country that rich in water resources is also very possible to be threatened with clean water. Indonesia is the fifth country with the largest water area in the world, after Brazil, Russia, China and Canada. In Indonesia the amount of water availability has reached approximately 694 billion cubic meters per year. This amount is potential, but in fact only around 23 percent have been used. From that 23 percent, it is recorded only 20 percent supply raw water needs of households, cities and industries, and the remaining 80 percent is used for irrigation (Ministry of Public Works).

The collaboration conducted by Klaten Regency and Surakarta City since Indonesia was colonized, is in the distribution of water from the umbul Cokro Tulung Klaten to the city of Surakarta to supply clean water for the people in Surakarta and surrounding areas. The collection of raw water from the natural sources of Cokro Tulung in Klaten Regency for drinking water customers in Surakarta City which has been going on since the Dutch colonial era.

Water use conflicts that occurred in Cokro Tulung Klaten makes the community began to experience the decreasing of water debit since there is an Aqua Plant and the construction of a PDAM which drained water with a powerful power pump. Thus, the water supply for the rice fields around the Cokro spring was reduced.

Another problem is when Klaten District Government raises the annual levy tariff on surface water. It considered by the Solo City Government as a unilateral decision and do not accept the decision. Since 2013 the Solo City Government has no longer paid the water retribution bill which is considered to have burdened the Surakarta City Regional Expenditure Revenues [1].

Based on the Central Java Provincial Regulation No. 2 of 2011, the Surakarta Municipal Water Supply Company must pay surface water tax to the Central Java Provincial Government every month according to the volume of water used. Thus, there is no more tariff payment directly to the Klaten city administration.

To prevent the damaging and decreasing water quality and quantity, it is necessary to manage or conserve water resources. The success of these efforts is determined to what extent the community values the existence and importance of water resources. Thus, this effort requires the community to involve. One of the steps of this effort is the willingness of the community to rehabilitate and protect environment in order to sustain and continue to provide benefits for human life. It can be a willingness of

\footnotetext{
*Corresponding author: mustari_faisal@yahoo.com
} 
the community to pay in order to improve the management of water resources conservation, especially at the Cokro Tulung water source in Klaten Regency.

The data generated from Indonesian Regional Water Utility Company (PDAM) Surakarta stated that the water quality of Cokro Tulung Spring Water experience fluctuation of production and distribution in the last four years. The production in 2014 are $23,512,293 \mathrm{~m}^{3}$ with the number of water distribution of 23,145,708 $\mathrm{m}^{3}$. In 2014 experienced decreasing of production and water distribution. Meanwhile, in 2016 experiencing increasing of $24,846,662 \mathrm{~m}^{3}$ production and $24,776,173 \mathrm{~m}^{3}$ of distribution.

Table 1. The number of production and distribution of PERUMDA

\begin{tabular}{|l|c|c|c|}
\hline Description & 2014 & 2015 & 2016 \\
\hline $\begin{array}{l}\text { Water } \\
\text { Production }\end{array}$ & $23,512,293$ & $23,282,040$ & $24,846,662$ \\
\hline $\begin{array}{l}\text { Water } \\
\text { Distribution }\end{array}$ & $23,145,708$ & $22,985,092$ & $24,776,173$ \\
\hline
\end{tabular}

Source: Regional Water Utility Company (PDAM) Surakarta / PERUMDA (2016).

The water service division from Indonesian Regional Water Utility Company (PDAM) Surakarta is divided into four areas that are north, east, west, and south.

Table 2. The area of water services

\begin{tabular}{|l|l|c|}
\hline No. & \multicolumn{1}{|c|}{ Services Area } & 2016 \\
\hline North Area & \\
\hline 1. & Population & 110,316 \\
\hline 2. & The number of household customer & 18,185 \\
\hline 3. & The average use $\left(\mathrm{m}^{3}\right)$ & 19 \\
\hline East & Area & \\
\hline $1 . \quad$ & Population & 74,950 \\
\hline 2. & The number of household customer & 8,590 \\
\hline 3. & The average use $\left(\mathrm{m}^{3}\right)$ & 16 \\
\hline West area & \\
\hline 1. & Population & 128,739 \\
\hline 2. & The number of household customer & 14,133 \\
\hline 3. & The average use $\left(\mathrm{m}^{3}\right)$ & 20 \\
\hline South area & \\
\hline 1. & Population & 200,166 \\
\hline 2. & The number of household customer & 19,036 \\
\hline 3. & The average use $\left(\mathrm{m}^{3}\right)$ & 16 \\
\hline
\end{tabular}

Source: Regional Water Utility Company (PDAM) Surakarta / PERUMDA (2016).

Those four areas are from the source of PERUMDA raw water, that are Cokro Tulung spring water that has 383 liter/second installed capacity, 22 active wells that have total capacity of 272,261 liter/second, that equipped 5 Water Processing Installation (IPA) Fe, Mn, and 2 buah IPA (Water Processing Installation) that are IPA Jurug \& IPA Jebres that have capacity of 127 liter/second (raw water Bengawan Solo).

The implementation of water resources management or conservation in the upstream level must be supported by various parties. For this case are water management and utilization in order to encourage the efficient and responsible utilization of natural resources. There are still many people who consume too much water from what they should. In result, in can cause inefficiencies in environmental damage. Therefore, there should be an appropriate environmental service mechanism to regulate the use of water resources and to reduce irregularities in water use. Then, the appropriate payment of environmental service namely Payment for Environmental Services (PES) is expected to correct low deviation of the price of environmental services is zero when there is no payment for environmental services.

\section{Theoretical background}

\subsection{Conservation of water resources}

Conservation of water resources is an effort to maintain the existence, natural, and function, as well as the sustainability of water resources so that water always available in adequate quality and quantity to supply the needs of living things, both now and in the future. Water should be used optimally and be followed by appropriate conservation management from various parties. For example, apply conservation environmental services such as reforestation.

Reforestation is an action to manage watersheds as land resources. Reforestation is one of important activities that should be done conceptually to maintain, restore, overcome the environmental crisis, and improve the condition of the land. The land can be productive and function optimally, both water management and environmental protection [2]

Environmental services is defined as a whole concept of a natural system that provides a flow of goods and services that are beneficial to humans and the environment produced by natural ecosystem processes. Payment for Environmental Services (PES) is a marketbased instrument for conservation purposes, based on the principle that those who gain benefits from environmental services, must pay for the sustainability of environmental service providers, and those who produces these services must be compensated [3].

Environmental payment mechanism, according to the World Bank, is referred to in Wunder will be explained in Figure 1. [4]. Explanation of the scheme below, it can be concluded that the benefit providers or those who provide environmental services are the environment itself, which is managed by the parties in it and utilized by users from various circles.

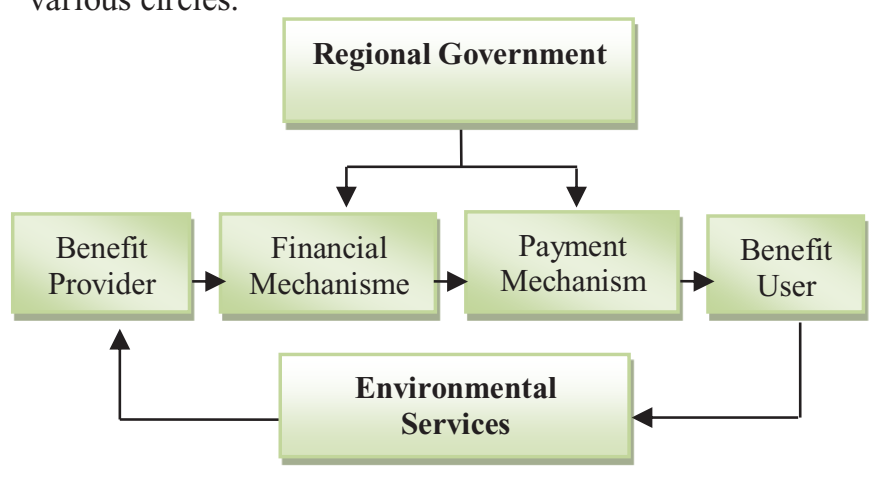

Fig. 1. Payment for environmental services. Source: World Bank (2003) in Wunder (2005). 
The benefit provider will design a financial mechanism so that the payment mechanism for environmental services that are suitable for the PES and can be accepted by the users. Previous study on Payment for Environmental Services (PES) in order to implement PES, there must be an initial investment in building infrastructure. Thus, PES will be created successfully and have institutions and policies to facilitate the conservation of many ecosystem services [5].

\subsection{Willingness to pay (WTP)}

Willingness To Pay (WTP) is defined as the amount that a consumer is willing to pay to obtain an item or service. WTP calculations estimate how far the ability of individuals or communities in aggregate to pay in order to improve environmental conditions to conform to the desired standards, where WTP is the value of potential uses of natural resources and environmental services [6].

Research about the willingness to pay analysis of the community towards the payment of water resource services Cirahab, Bogor is Rp 101/liter/households while the total value of WTP is Rp 83,835,-/liter. The factors that influence the respondents' WTP value are influenced by the assessment of water quality, the amount of water needs, the distance of the house and the need for water [7]. In the other hand, a research conducted by Afifah found that factors that significantly affect WTP water environmental services for conservation partially are income, water use, perception of the importance of water conservation, gender, and education [8].

This study uses eight independent variables, namely sex, education, income, status of the house, perception of water quality, perception of water needs, perception of the importance of conservation, and home ownership.

Sex is the difference in physical form, nature and biological function between men and women which will determine their respective roles in carrying out their nature and efforts to continue the lineage. This study assesses that men tend to be more willing to pay more than women because women tend to be more responsible for various expenses because they are financial regulators in the household so that many considerations influence their decision making.

Education is an activity of learning knowledge, honing skills that are carried out through teaching, training, or research. This study assesses that higher educated people have good thinking patterns, so that the higher the level of education of a person, the awareness of the environment will also increase.

Revenue is the sum of the real income of all members of the household in the household which includes the income of the household such as the father, the mother, and the child who has worked. Revenue is expected to have an effect on the level of willingness to pay for water resource conservation where the higher the family income is the higher the willingness to pay for the conservation of water resources. House ownership is right over a property that live in whether private house, rent house, and living with parents. House ownership will affect WTP due to cost minimization including house rent expense that can allocate the budget to WTP.
Water quality is a measure of the condition of water that is suitable for human consumption, tested from its physical, chemical and biological characteristics. Community perception of water quality will determine willingness to pay. If the water quality is good and is suitable for consumption, the public will pay, and vice versa.

The water source used to fulfil daily needs is from PERUMDA and water wells. Customers who received clean water from PERUMDA are presumed to increase environmental awareness. Water needs is how much water is needed in daily activities. Perception of water needs will affect the willingness to pay for conserve water resources because people who have more water needs have the opportunity to be willing to pay higher payments for environmental services.

Conservation is a preservation or protection against the environment so that its beauty is maintained. The perception of the importance of water conservation causes public awareness to play a role in safeguarding the forest by planting and maintaining facilities for water supply infrastructure as an effort to conserve water.

\section{Research methodology}

\subsection{Research location}

This research has been done in Surakarta, precisely in the southern region of Surakarta, Laweyan District, Central Java, Indonesia. This research focuses in the Municipal Waterworks (PDAM) customers areas, Laweyan District that covers Jajar, Kerten, Pajang, and Sondakan areas. The reason behind the research location is because the water resource from Municipal Waterworks (PDAM) in this area is from Cokro Tulung. The following map is a map of Surakarta with the distribution of customers based on region and source of production.

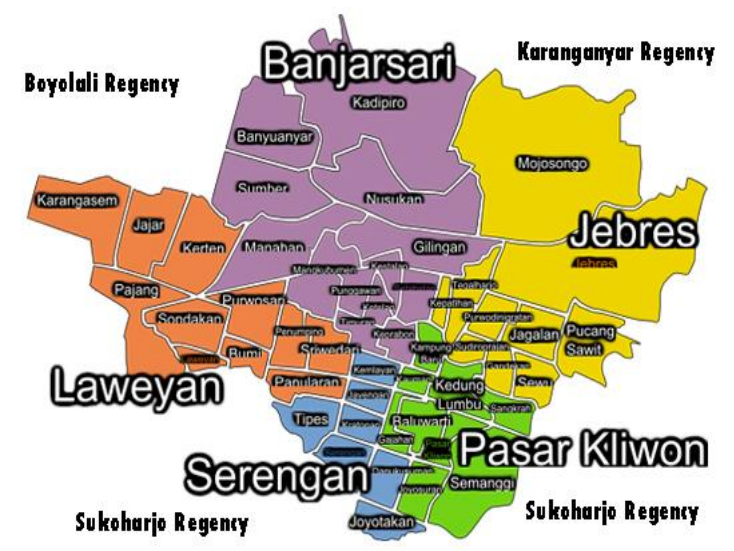

Fig. 2. Map of Surakarta.

Source: Surakarta city public works department (2018).

The distribution of customers by region is divided into four regions, namely the northern region (yellow), the Banjar area (purple), the eastern region (green), and the south (orange and blue). This research focuses on orange color (Laweyan village). The following data is source of production from Laweyan sub-district: 
Table 3. Production resource in south Surakarta area.

\begin{tabular}{|c|l|c|}
\hline No. & \multicolumn{1}{|c|}{$\begin{array}{c}\text { Resource of } \\
\text { Production }\end{array}$} & Total Debit \\
\hline 1. & Karangasem well & 6.19 litres / second \\
\hline 2. & $\begin{array}{l}\text { Cokro Tulung water } \\
\text { resource }\end{array}$ & 237 litres / second \\
\hline \multicolumn{2}{|c|}{ Total } & 243.19 litres / seconds \\
\hline
\end{tabular}

Source: PERUMDA Surakarta (2017).

\subsection{Population and sample}

The population in this research is the Surakarta Municipal Waterworks (PDAM) customers, especially from District Laweyan in Jajar, Kerten, Pajang, and Sondakan area with 2,657 in total customers. The sampling method that is used in this study is proportionate stratified random sampling because in estimating the WTP value, it will be different per group of households (R2, R3, R4, and N1).

$$
\mathrm{n}=\frac{\mathrm{N}}{1+\mathrm{N}(\mathrm{e})^{2}}
$$

Remarks:

$\mathrm{n}$ : total sample

$\mathrm{N}$ : total population

e : standard error $(10 \%)$

1 : constant

The total sample is 96, this is obtained from Slovin formula calculation. In order to anticipate the error answer/ outlier, the respondent is added by $10 \%$, so the total respondent is 106 respondents. The respondents' composition are 51 respondents for R2, 27 respondents for R3, 15 respondents for R4, and 13 respondents for N1.

\subsection{Research type}

This research is a descriptive quantitative with survey and interview method using questionnaire. Questionnaire is a very important instrument in this research because the data that will be processed mostly came from the questionnaire. The research framework is explained by figure 3 as follow:

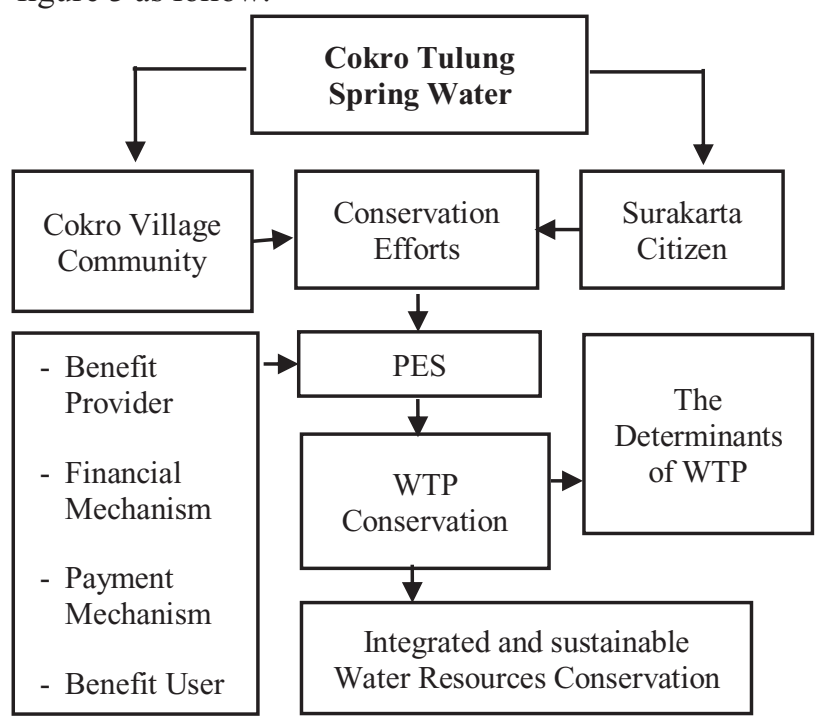

Fig. 3. Research framework.

\subsection{WTP analysis for water resource conservation}

Contingent Valuation Method (CVM) is a survey technique method to assess the value or price of a commodity that has no market price likely environment goods [9].

Willingness to pay can be analyzed by using CVM. The steps of CVM analysis can be analyzed using CVM approach $[6,10]$.

\subsubsection{Make a hypothetical market}

The hypothetical market is built to provide a reason why people should pay for environmental services for the conservation of water resources in the Cokro Tulung spring/water resource. In addition, the questionnaire also needs to explain the changes that will occur if there is a desire by the public to pay.

\subsubsection{Offers the value of WTP}

Offer the value of WTP can be done by using open-ended questionnaires and techniques to determine public awareness seen from the lowest value of WTP to the highest value can be known estimates of payment of environmental conservation services for water resources by the community.

\subsubsection{Estimate the average WTP value}

Calculation of the offer value uses an average value, then a value that is higher than the actual value is obtained, therefore it is better to use the middle value so that it is not affected by a large enough supply range.

$$
E W T P=\left(\frac{\sum_{\mathrm{i}=1}^{\mathrm{n}} \mathrm{Wi}}{n}\right)
$$

Remarks:

EWTP : estimated average WTP

$W_{i} \quad:$ WTP- $i$

$n \quad:$ respondent

$i \quad$ : respondent- $i$ who agree to pay

$1 \quad$ : constant

\subsubsection{Calculate the total WTP}

The estimated total value of WTP can be obtained by the following formula:

$$
T W T P=\sum_{\mathrm{i}=1}^{\mathrm{n}} W T P \mathrm{i}\left(\frac{n i}{N}\right) \mathrm{P}
$$

Remarks:

TWTP : total WTP

$N \quad$ : total sample

$P \quad:$ : total population 


\subsection{Analysis of factors that influence the value of WTP for environmental services conservation}

To analyse which variables, influence the WTP conservation of water resources in the Cokro Tulung spring/water resource, we can use the Ordinary Leas Square model that can be formulated as follows:

$$
\begin{gathered}
Y=\beta 0+\beta 1 X 1 i+\beta 2 X 2 i+\beta 3 X 3 i+\beta 4 X 4 i+ \\
\beta 5 X 5 i+\beta 6 X 6 i+\beta 7 X 7 i+\beta 8 X 8 i+\varepsilon i
\end{gathered}
$$

Remarks:

Y : Willingness to Pay on water resource conservation (rupiahs/month)

$\mathrm{X} 1 \quad: \operatorname{sex}(\mathrm{D}=1$ : male, $\mathrm{D}=2$ : female $)$

$\mathrm{X} 2$ : education (year)

$\mathrm{X} 3 \quad$ : income (Rp/month)

$\mathrm{X} 4$ : water resource that is used $(\mathrm{D}=1$ : PERUMDA, $\mathrm{D}=2$ : PERUMDA and well)

X5 : house ownership ( $D=1$ : self-owned, $D=2$ : rent, $\mathrm{D}=3$ : living with parents))

X6 : water quality perception $(\mathrm{D}=5$ "very clear", $\mathrm{D}=4$ "clear", $\mathrm{D}=3$ "slightly clear", $\mathrm{D}=2$ "dirty", $\mathrm{D}=1$ "very dirty")

$\mathrm{X} 7$ : water needed perception $(\mathrm{D}=5$ "very often", $\mathrm{D}=4$ "often", $\mathrm{D}=3$ "slightly often", $\mathrm{D}=2$ "rarely", $\mathrm{D}=1$ "very rarely)

X8 : conservation importance perception $(D=1$ : yes, $\mathrm{D}=0$ : no)

Bo $\quad$ : intercept

$\beta 1 . .87$ : regression coefficient

$i \quad$ : respondent $-1(\mathrm{i}=1,2, \ldots, \mathrm{n})$

$\varepsilon \quad:$ error

\section{Result and discussion}

\subsection{Respondent characteristics}

Based on the interview from 106 respondents, we found the social-economy characteristic of the respondents as follows (see table 4)

\begin{tabular}{|c|c|c|c|}
\hline Variable & Descriptions & Freq. & Perc. \\
\hline \multirow{2}{*}{ Sex } & Male & 54 & $50.9 \%$ \\
\hline & Female & 52 & $49.1 \%$ \\
\hline \multirow{7}{*}{ Age } & $<24$ years old & 3 & $2.8 \%$ \\
\hline & $25-34$ years old & 10 & $9.4 \%$ \\
\hline & $35-44$ years old & 14 & $13.1 \%$ \\
\hline & $45-54$ years old & 36 & $33.9 \%$ \\
\hline & $55-64$ years old & 21 & $19.6 \%$ \\
\hline & $65-74$ years old & 16 & $14.9 \%$ \\
\hline & $75-84$ years old & 6 & $5.5 \%$ \\
\hline \multirow{6}{*}{ Education } & Elementary School & 2 & $1.9 \%$ \\
\hline & Junior High School & 7 & $6.6 \%$ \\
\hline & Senior High School & 49 & $46.2 \%$ \\
\hline & Diploma 3 & 13 & $12.3 \%$ \\
\hline & $\begin{array}{l}\text { Diploma 4, } \\
\text { Undergraduate }\end{array}$ & 32 & $30.2 \%$ \\
\hline & Graduate & 3 & $2.8 \%$ \\
\hline \multirow{2}{*}{$\begin{array}{l}\text { Monthly } \\
\text { Family } \\
\text { Income }\end{array}$} & $<$ Rp. 500.000,- & 0 & $0 \%$ \\
\hline & $\begin{array}{l}\text { Rp. } 500.001- \\
\text { Rp. } 1.000 .000,-\end{array}$ & 5 & $4.7 \%$ \\
\hline
\end{tabular}

Table 4. Respondents' social-economy characteristic.

\begin{tabular}{|c|c|c|c|}
\hline Variable & Descriptions & Freq. & Perc. \\
\hline & $\begin{array}{l}\text { Rp. 1.000.001 - } \\
\text { Rp. 1.500.000,- }\end{array}$ & 10 & $9.4 \%$ \\
\hline & $\begin{array}{l}\text { Rp. 1.500.001 - } \\
\text { Rp. 2.000.000,- }\end{array}$ & 19 & $17.9 \%$ \\
\hline & $\begin{array}{l}\text { Rp. 2.000.001 - } \\
\text { Rp. 3.000.000,- }\end{array}$ & 28 & $26.4 \%$ \\
\hline & $>$ Rp.3.000.001,- & 44 & $41.5 \%$ \\
\hline \multirow[b]{2}{*}{$\begin{array}{l}\text { Water } \\
\text { Resources }\end{array}$} & PERUMDA water & 45 & $42.5 \%$ \\
\hline & $\begin{array}{l}\text { PERUMDA water } \\
\text { and well water }\end{array}$ & 61 & $57.5 \%$ \\
\hline \multirow{5}{*}{$\begin{array}{l}\text { Water Quality } \\
\text { Perception }\end{array}$} & Very Clear & 32 & $30.2 \%$ \\
\hline & Clear & 61 & $57.5 \%$ \\
\hline & Slightly Clear & 12 & $11.3 \%$ \\
\hline & Dirty & 1 & $9 \%$ \\
\hline & Very Dirty & 0 & $0 \%$ \\
\hline \multirow{2}{*}{$\begin{array}{l}\text { PES } \\
\text { Knowledge }\end{array}$} & Understand & 16 & $15.1 \%$ \\
\hline & Don't Understand & 90 & $84.9 \%$ \\
\hline \multirow{2}{*}{$\begin{array}{l}\text { Conservation } \\
\text { Type }\end{array}$} & Greening & 78 & $73.6 \%$ \\
\hline & Et cetera & 28 & $26.4 \%$ \\
\hline
\end{tabular}

Source: Primer data, processed (2018).

Survey shows that $50.9 \%$ respondent is male and $49.1 \%$ is female. This shows that the majority of respondents are the head of households.

The next social-economy character is households' monthly total income. In this research, the households' monthly total income is the total income from all of the family members. The survey shows that the highest

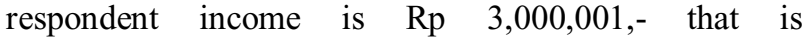
approximately $41.5 \%$ from the respondents. From table 4 we can see that $53.7 \%$ of the respondents have income more than $\mathrm{Rp} 1,000,000,-$.

Respondents in this research are customers of Municipal Waterworks (PDAM) of Surakarta City. However, Municipal Waterworks is not their only water resource, well water is used as well. It is proved that $57.5 \%$ of the respondents use the Municipal Waterworks (PDAM) and well water. While $42.5 \%$ of the rest is only used the Municipal Waterworks (PDAM). The reasons why customers still utilize well water is to economize the use of water from PERUMDA and water distribution that is not flow smoothly at some customers. The survey results show that there are $73.6 \%$ of respondents intend to do greening around Cokro Tulung spring.

\subsection{Environment service value towards water resource conservation willingness to pay}

Based on the interview from 106 respondents, it is found that the majority of respondents (90 people or $85 \%$ respondent) agreed on paying for water resource conservation. The reason why they agreed on paying for water resource conservation is in order to get cleaner water. They do hope that when the conservation is done, it will increase the water quality and keep the water quantity as well. 
Willingness To Pay (WTP)

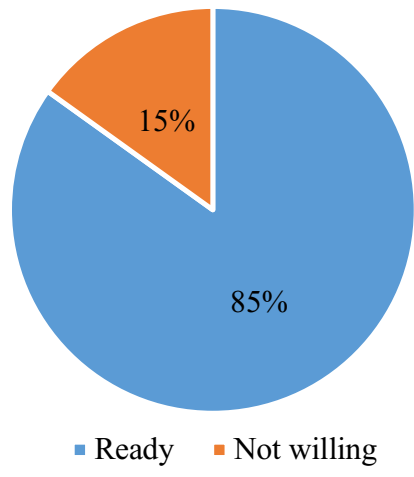

Fig. 4. Willingness to pay percentage.

Some of the respondents also agreed on paying with reason that they thought that the next generation will also need clean water, so the conservation is needed. Some of the respondents also agreed on paying with reason to help the developer to fund the water conservation. From the 90 of the respondent who agreed on paying, 86 of them agreed if environment service cost should be added on the water price managed by the Municipal Waterworks (PDAM). Meanwhile, the 4 other respondents agreed if the environment service cost is managed by institution outside of the Municipal Waterworks (PDAM).

There are $15.5 \%$ or 16 people don't willing to pay the conservation fee. The reason is that they don't have excess money to pay that fee. They consider that as government responsibility, and conservation is not necessary because the water is already pure.

\subsection{Willingness to pay value for water resource conservation}

Based on the interview, it is found that value of willingness to pay towards water resource conservation in Cokro Tulung water resource per household/respondent is quite vary. In deciding the value of willingness to pay, respondents tend to choose price in multiple with $\mathrm{Rp} 500$,such as Rp 1,000,-; Rp 1,500,-; Rp 2,000,-; R p2,500,until $\mathrm{Rp} 10,000,-$. Here are the data calculation of willingness to pay on table 5 .

Table 5. Willingness to pay calculation

\begin{tabular}{|l|l|l|l|l|l|}
\hline No. & $\begin{array}{c}\text { Customer } \\
\text { Group }\end{array}$ & $\begin{array}{c}\text { Total } \\
\text { WTP } \\
(\text { Rp) }\end{array}$ & $\begin{array}{c}\text { Min. } \\
\text { WTP } \\
(\text { Rp) }\end{array}$ & $\begin{array}{c}\text { Max. } \\
\text { WTP } \\
\text { (Rp) }\end{array}$ & $\begin{array}{c}\text { Avg. } \\
\text { WTP } \\
\text { (Rp) }\end{array}$ \\
\hline 1. & R2 & 80.500 & 500 & 5.000 & 1.872 \\
\hline 2. & R3 & 68.000 & 1.000 & 8.000 & 3.238 \\
\hline 3. & R4 & 36.000 & 1.000 & 5.000 & 2.769 \\
\hline 4. & N1 & 50.000 & 2.000 & 10.000 & 3.846 \\
\hline
\end{tabular}

Source: Primer data, processed (2018).
Table 5 shows the WTP value for the four customer groups is vary. The lowest WP value that will be paid by R2 (household 2) is Rp 500,- R3 (household 3) is Rp 1,000,- R4 (household 4) is Rp 1,000,- and N1 (industry 1) is $\operatorname{Rp} 2,000,-$.

The average WTP from the four customer groups is vary. The average WTP on household 2 is Rp 1,872,household 3 is Rp 3,238,- household 4 is Rp 2,769,- and the industry 1 is $\operatorname{Rp~3,846,-.~This~result~shows~that~the~}$ first hypothesis that stated WTP management for the water resource conservation is high cost is not proved. However, it shows the opposite that WTP management for water resource conservation is low cost. A research done by Afifah regarding the environment service WTP in TWA Kerandangan Kabupaten Lombok Barat, the gained average WTP of customer in Kerandangan is Rp 8,100 ,- so, the agregat WTP is Rp 1,352,700-,/month and Rp 16,232,400,-/year.

The relatively low WTP shows that the four groups of customer/respondents are not yet able to estimate the maximum economic assessment toward conservation. Besides that, the majority of respondents' water resource is from PERUMDA and well water. These came as their considerations on assessing the water resource conservation cost.

Most of the respondents are not yet understand about the environment service payment for water resource conservation so that they gave the low value on WTP. The ability to answer the question about the willingness to pay during the interview was not good. They tent to lower the WTP value.

\subsection{Total value of willingness to pay}

The total value of willingness to pay on Cokro Tulung water resource conservation is calculated to know the estimation of the total economy. Table 6 shows the estimation of total value of the willingness to pay.

Table 6. Estimated total value of willingness to pay

\begin{tabular}{|l|l|l|l|l|}
\hline $\begin{array}{l}\text { No } \\
\cdot\end{array}$ & $\begin{array}{c}\text { Customer } \\
\text { Group }\end{array}$ & $\begin{array}{c}\text { Avg. } \\
\text { WTP } \\
\text { (Rp) }\end{array}$ & Population & $\begin{array}{c}\text { Total } \\
\text { (Rp) }\end{array}$ \\
\hline 1. & R2 & 1,872 & 1,295 & $2,424,240$ \\
\hline 2. & R3 & 3,238 & 679 & $2,198,602$ \\
\hline 3. & R4 & 2,769 & 366 & $1,013,454$ \\
\hline 4. & N1 & 3,846 & 317 & $1,219,182$ \\
\hline \multicolumn{2}{|l}{ Total (R2, R3, R4, N1) } & $6,855,478$ \\
\hline
\end{tabular}

Source: Primer data, processed (2018).

Based on table 6 above, the gained WTP of the Municipal Waterworks (PDAM) Surakarta's customer, especially in Jajar Village, Kerten, Pajang, and Sondakan, Laweyan District is Rp 1,872,- per household. We can say that the aggregate WTP is Rp 2,424,240,-/month and Rp $29,090,880$,-/year, for the household 3 is $\mathrm{Rp} 3,238,-$, so the aggregate WTP is Rp 2,198,602,-/month and Rp 26,383,224,-/year, for household 4 is Rp 2,769,-, so the aggregate WTP is Rp 1,013,454,-/month and Rp $12,161,448,-$ year, and the industry group 1 is $\mathrm{Rp} 3,846$,- 
so the aggregate WTP is Rp 1,219,182,-/month and Rp $14,630,184,-/$ year.

According to 2016 data from Indonesian Regional Water Utility Company (PDAM) Surakarta, the R2 customers are 35,991, the R3 customers are 11,026, the R4 customers are 5,868, and N1 customers are 4,563. Thus, the WTP aggregate measurement for each classification of R2, R3, R4, dan N1 customers are Rp $67,375,152,-/$ month, $\quad$ Rp 35,702,188,-/month, Rp $16,248,492,-/$ month, and Rp 17,549,298,-/month respectively.

\subsection{Variables that determined WTP value}

The result of multiple linear regression is shown on the table 7 below:

Table 7. Result on multiple linear regression

\begin{tabular}{|l|c|c|}
\hline \multicolumn{1}{|c|}{ Variabel } & Coefficient & Sig. \\
\hline (Constant) & 347.329 & 0.952 \\
\hline Sex & -401.076 & 0.232 \\
\hline Education & 125.865 & $0.076^{* *}$ \\
\hline Monthly household income & -58.682 & 0.882 \\
\hline House ownership & -150.128 & 0.685 \\
\hline Water resource that is used & -649.372 & 0.117 \\
\hline Water quality perception & 267.787 & 0.297 \\
\hline Water needed perception & -161.276 & 0.506 \\
\hline $\begin{array}{l}\text { Conservation importance } \\
\text { perception }\end{array}$ & 2713.245 & $0.000^{*}$ \\
\hline$R^{2}$ & 0.293 & - \\
F Statistic / Count & 5.023 & 0.000 \\
\hline
\end{tabular}

Remarks: ${ }^{*}$ sig. on $\alpha 5 \%$ and ${ }^{* *}$ sig. on $\alpha 10 \%$.

According the multiple linear regression calculation, the $\mathrm{R}$ squared value from the 106 respondents is $29.3 \%$ and the rest, $70.7 \%$ of the influenced variables outside the model. Besides that, the $\mathrm{F}_{\text {count }}$ is 5.023 with significance value 0.000 dan $F_{\text {table }} 2.10$. When $F_{\text {count }}$ is bigger than $F_{\text {table }}$ means that $\mathrm{Ho}$ is rejected and $\mathrm{Ha}$ is accepted. We can conclude than the independent variable have significant impact on the water resource conservation by $5 \%$.

Based on the multiple linear regression test on table 7, it shows that education and conservation importance perception variable have significant impact on the WTP value. Here is the model:

$W T P=347.329+125.865$ (education) +2713.245 (conservation importance perception)

\subsubsection{Education}

According to the hypothesis test, the coefficient variable value is positive 125.865 with significance value below $10 \%$, as 0.076 . This shows that education variable has significant impact toward WTP value, which mean that every increase on the education by 1 year will increase the WTP by Rp 125.865. In short, the higher education of the people, the higher the willingness to pay or the individual WTP value. This conclusion is linear with the research done by Afifah. Education can upgrade knowledge, information, educate and change the way of thinking. The higher the level of education of a person, the environmental awareness will also increase.

\subsubsection{Conservation importance perception}

Based on the hypothesis test, coefficient value on conservation importance perception is positive 2713.245 with significance lower than $5 \%(0.000)$. This shows that conservation importance perception variable is has a positive significant impact on the WTP value, where the increase on every conservation by $1 \%$ will increase the WTP value by Rp $2,713,245,-$. We can say that the higher conservation importance perception on people, the higher WTP value/ individual WTP value will be gained. This is linear with research done by Afifah. Conservation concern creates community awareness to preserve forest by doing reforestation and preservation of water demand infrastructure as conservation effort. The perception of water conservation importance can lead to the community awareness to preserve their environment as and effort of water conservation.

Other independent variable such as sex, house ownership, water resource that is used, water quality perception, water needed perception, and household income don't have significant impact on WTP value

\section{Conclusion and recommendation}

\subsection{Conclusion}

Based on the result and discussion on the previous chapter, we might conclude that:

1. The average WTP on R2 is Rp $1,872,-$ so that the aggregate WTP is Rp 2,424,240,-/month ; R3 is Rp 3,238 ,- so that the aggregate WTP is Rp 2,198.602,-/month, R4 is Rp 2,769,-- so that the aggregate WTP

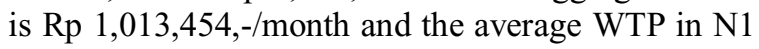
is Rp 3,846,- so that the aggregate WTP is Rp $1,219,182,-$ /month.

2. The Education and conservation importance perception variable have significant impact on water resource conservation WTP value.

3. The survey shows that the $78 \%$ of the respondents agreed if greening program will be done in Cokro Tulung water resource area.

\subsection{Recommendation}

Based on the study of the environment conservation service willingness to pay in Surakarta city, especially in Laweyan District, the suggestions are as follow:

1. Socialisation is needed, especially to the PERUMDA customers regarding the payment mechanism of the environment service that will be done and also the positive and negative impacts towards the environment service payment policy.

2. This must be supported by the constitution regarding the environment service payment both in the national and local level. 
3. Fund management is needed to support the environment service in order to manage the fund in line with the conservation mission.

\section{References}

1. Y.U. Permatasari, Conflict resolution managing the source of the Cokro spring, UNS Digital Library, (2017)

2. T. Notohadiprawiro, Watershed Management \& reforestation program, FP UGM, 8-1-1981 to 4-31981 (2006)

3. S. Pagiola, Environmental services payment in central America, Training Course World Bank Institute 33, No. 2, pp. 237-253 (2005)

4. S. Wunder S. Engel, and S. Pagiola, Designing payments for environmental services, Payment 65, no. 4, pp. 663-674, (2008)

5. K. J. Wendland, M. Honzák, R. Portela, B. Vitale, S. Rubinoff, and J. Randrianarisoa, Targeting and implementing payments for ecosystem services, Payment 69, no. 11, pp. 2093-2107 (2010)

6. A. Fauzi, Economics of natural resources and environment, Gramedia Main Library, (2006)

7. A. Merryna, Analysis community WTP, Faculty of Economics and Management ITB, (2009)

8. K.N. Afifah, WTP analysis of environmental water services, EKOSAINS 5, No. 2 (2013)

9. A. Yakin, Resource and environmental economics, CV. Akademika Presindo, (1997) 